\title{
Soot microphysical effects on liquid clouds, a multi-model investigation
}

\author{
D. Koch ${ }^{1,2, *}$, Y. Balkanski ${ }^{3}$, S. E. Bauer ${ }^{1,2}$, R. C. Easter ${ }^{8}$, S. Ferrachat ${ }^{4}$, S. J. Ghan ${ }^{8}$, C. Hoose ${ }^{7,10}$, T. Iversen ${ }^{5}$, \\ A. Kirkevåg ${ }^{5}$, J. E. Kristjansson ${ }^{10}$, X. Liu ${ }^{8}$, U. Lohmann ${ }^{4}$, S. Menon ${ }^{9}$, J. Quaas ${ }^{6}$, M. Schulz ${ }^{3,10}$, Ø. Seland ${ }^{5}$, \\ T. Takemura ${ }^{11}$, and N. Yan $^{3}$ \\ ${ }^{1}$ Columbia University, New York, NY, USA \\ ${ }^{2}$ NASA GISS, New York, NY, USA \\ ${ }^{3}$ Laboratoire des Sciences du Climat et de l'Environnement, Gif-sur-Yvette, France \\ ${ }^{4}$ Institute of Atmospheric and Climate Science, ETH Zurich, Switzerland \\ ${ }^{5}$ Norwegian Meteorological Institute, Oslo, Norway \\ ${ }^{6}$ Max Planck Institute for Meteorology, Hamburg, Germany \\ ${ }^{7}$ Karlsruhe Institute of Technology, Institute for Meteorology and Climate Research, Karlsruhe, Germany \\ ${ }^{8}$ Pacific Northwest National Laboratory, Richland, USA \\ ${ }^{9}$ Lawrence Berkeley National Laboratory, USA \\ ${ }^{10}$ Department of Geosciences, University of Oslo, Oslo, Norway \\ ${ }^{11}$ Kyushu University, Fukuoka, Japan \\ *now at: Department of Energy, DC, USA
}

Received: 22 September 2010 - Published in Atmos. Chem. Phys. Discuss.: 13 October 2010

Revised: 17 January 2011 - Accepted: 21 January 2011 - Published: 7 February 2011

\begin{abstract}
We use global models to explore the microphysical effects of carbonaceous aerosols on liquid clouds. Although absorption of solar radiation by soot warms the atmosphere, soot may cause climate cooling due to its contribution to cloud condensation nuclei $(\mathrm{CCN})$ and therefore cloud brightness. Six global models conducted three soot experiments; four of the models had detailed aerosol microphysical schemes. The average cloud radiative response to biofuel soot (black and organic carbon), including both indirect and semi-direct effects, is $-0.11 \mathrm{Wm}^{-2}$, comparable in size but opposite in sign to the respective direct effect. In a more idealized fossil fuel black carbon experiment, some models calculated a positive cloud response because soot provides a deposition sink for sulfuric and nitric acids and secondary organics, decreasing nucleation and evolution of viable CCN. Biofuel soot particles were also typically assumed to be larger and more hygroscopic than for fossil fuel soot and therefore caused more negative forcing, as also found in previous studies. Diesel soot (black and organic carbon) experiments had relatively smaller cloud impacts with five
\end{abstract}

Correspondence to: D. Koch

(dorothy.koch@science.doe.gov) of the models $< \pm 0.06 \mathrm{Wm}^{-2}$ from clouds. The results are subject to the caveats that variability among models, and regional and interrannual variability for each model, are large. This comparison together with previously published results stresses the need to further constrain aerosol microphysical schemes. The non-linearities resulting from the competition of opposing effects on the CCN population make it difficult to extrapolate from idealized experiments to likely impacts of realistic potential emission changes.

\section{Introduction}

Black carbon, generated by incomplete combustion of fossil and biofuels, is dark and therefore absorbs radiation in the atmosphere and on snow, promoting warming of the air and melting of the snow. Through these mechanisms it contributes to global warming. However black carbon, together with other aerosol species, also affects clouds, and these cloud perturbations may alter climate more than the aerosol direct radiative changes do. Black carbon has multiple effects on clouds and some of these are potentially cooling.

Published by Copernicus Publications on behalf of the European Geosciences Union. 
However, black carbon (BC) is not emitted in isolation, therefore the climate impacts of black carbon cannot be isolated from co-emitted species. Organic carbon (OC), a brighter and more hygroscopic carbonaceous aerosol species (e.g. Kanakidou et al., 2005), is commonly co-emitted with BC, especially from burning of biofuels. Sulfur dioxide, gaseous precursor to sulfate, may also be co-emitted, particularly in some fossil fuel sources such as coal. Here we loosely refer to $\mathrm{BC}$ and $\mathrm{OC}$ together as soot and focus particularly on the impacts of soot on some of its cloud effects. We note that soot from fossil fuel generally has smaller OC to $\mathrm{BC}$ ratio compared with biofuel, where biofuels sources include combustion of domestic wood, agricultural and animal waste and charcoal (e.g. Bond et al., 2004).

Soot may affect clouds in at least three ways. First, aerosol absorption of solar radiation in the atmosphere perturbs the thermal structure of the atmosphere and changes cloud distribution. This has been called the semi-direct effect and the soot semi-direct effect may either promote or reduce cloud cover, depending upon the altitude of the aerosol relative to the cloud layer and meteorological conditions (e.g. reviewed by Koch and Del Genio, 2010). Second, black carbon particles may act as ice nuclei and change ice or mixed-phase clouds, resulting in positive (e.g. Lohmann and Hoose, 2009 for mixed; Liu et al., 2009 for ice) or negative (e.g. Penner et al., 2009 for ice) cloud effect depending mostly on the background ice nucleation mechanism. In this study we do not consider the effects of $\mathrm{BC}$ on ice clouds, but rather focus on the effects of $\mathrm{BC}$ on liquid droplets within liquid or mixed phase clouds. We also note that the effects of $\mathrm{BC}$ on icephase clouds as observed in the field and laboratory are very uncertain (e.g. Kärcher et al., 2007).

Our primary interest is the effect of soot on liquid clouds due to its alteration of the aerosol cloud condensation nuclei $(\mathrm{CCN})$ population. Increased numbers of $\mathrm{CCN}$ generally increase the cloud droplet number concentration (CDNC), which then enhance cloud brightness and possibly increase cloud lifetime, commonly referred to as cloud albedo and lifetime effects (or more generally, indirect effects). The impact of soot on CCN may depend on at least four factors. First, soot is a primary particle, meaning that it is emitted in particulate form; secondary aerosols are first emitted as a gas that later converts to particulate form. As a primary particle, soot may increase aerosol number. Secondly, however, soot forms a deposition site for sulfuric acid gas and other secondary species which might otherwise nucleate or condense upon other particles; a soot-sulfate particle may be an inferior $\mathrm{CCN}$ compared with the alternative particles. Thirdly, the larger the $\mathrm{OC}$ to $\mathrm{BC}$ ratio, the better its $\mathrm{CCN}$ activity due to increased hygroscopicity. Fourthly, larger particles activate more easily, so a tiny (e.g. diesel) particle is less likely to form a CCN than a larger (e.g. biofuel) particle would. Thus, in general, particle activation (conversion of the particle to a $\mathrm{CCN}$ ) requires that the particle be large enough and sufficiently hygroscopic. We rely on global aerosol-climate models to estimate aerosol indirect effects. In order to study the multiple and complex effects of soot on $\mathrm{CCN}$, models with aerosol microphysics, including information on particle mixing state and size, are required.

Three previous studies using global models with aerosol microphysical schemes have isolated soot indirect effects. Kristjansson (2002) used the NCAR CCM3 and estimated the cloud radiative response (change in cloud radiative effect) to all black carbon (fossil, biofuel and open biomass) to be $-0.1 \mathrm{Wm}^{-2}$. Bauer et al. (2010) performed four soot reduction experiments in the GISS GCM with the MATRIX aerosol microphysical scheme, reducing $50 \%$ of all $\mathrm{BC}$, all fossil fuel BC, all biofuel BC and OC, and all diesel BC and OC. The respective cloud radiative responses to soot (including indirect and semi-direct effects) were $-0.12,+0.05$, -0.20 and $+0.05 \mathrm{Wm}^{-2}$ (where we reverse the sign in order to provide soot effect rather than soot reduction effect). For all experiments except the biofuel experiment, the cloud droplet number concentration decreased as soot increased because soot provided increased surface for sulfate condensation, while reduced soot increased the number of viable $\mathrm{CCN}$. However the biofuel soot was relatively hygroscopic and therefore had a stronger indirect effect. The negative cloud response to the $50 \% \mathrm{BC}$ experiment was apparently a semi-direct effect. A third study is Chen et al. (2010) in a different version of the GISS model with the TOMAS aerosol microphysical scheme. They calculated a -0.13 and $-0.31 \mathrm{Wm}^{-2}$ indirect effect (isolated from semi-direct effects) cloud response to $50 \%$ of fossil fuel $\mathrm{BC}$ and $\mathrm{OC}$ and to $50 \%$ of all sources of $\mathrm{BC}$ and $\mathrm{OC}$ respectively. The stronger response in the second experiment was attributed to the larger sizes of biofuel soot; these particles were probably also more hygroscopic. Another study, Jacobson (2010), used the GATOR model to simulate soot effects on climate. Although he did not isolate the liquid cloud microphysical effects of soot, he did find that biofuel soot increased liquid cloud cover while fossil fuel soot decreased cloud cover. These studies (Bauer et al., 2010; Chen et al., 2010; Jacobson, 2010) found that the cloud response is more negative for biofuel compared with fossil fuel soot. However while Chen et al. (2010) calculated negative response for both fossil fuel and biofuel, Bauer et al. (2010) and Jacobson (2010) found positive response to fossil fuel.

If the BC indirect effect is sufficiently negative, this cloud response could cancel much of the direct radiative benefits of $\mathrm{BC}$ reduction. Given the variety of results from the previous soot indirect effect studies and the uncertainties associated with the aerosol microphysical schemes and in the indirect effect generally, it is helpful to consider multiple models' clouds responses to soot. Here we analyze and compare the responses of six models (including that of Bauer et al., 2010) to reductions of black carbon using three different soot-reduction experiments.

This study is largely a follow-up to the earlier AeroCom study of Quaas et al. (2009) that considered the liquid cloud 
Table 1. Soot emissions (not included are the non-soot emissions: sulfur (145 Tg Sy $\mathrm{T}^{-1}$ for 2000 and $34 \mathrm{Tg} \mathrm{S}^{-1}$ for 1750), dust $\left(1680 \mathrm{Tg}^{-1}\right)$, sea-salt $\left(7900 \mathrm{Tg}^{-1}\right)$ and $14 \mathrm{Tg}$ OC from natural terpene sources).

\begin{tabular}{lrrr}
\hline Description & $\begin{array}{r}\text { BC Emission } \\
\mathrm{Tg} \mathrm{yr}^{-1}\end{array}$ & $\begin{array}{r}\mathrm{OC}^{2} \text { Emission } \\
\mathrm{Tg} \mathrm{yr}^{-1}\end{array}$ & OC/BC \\
\hline Fossil fuel (reduced in FF) & 3.0 & 0. & 0 \\
Biofuel (reduced in BF) & 1.6 & 6.4 & 4 \\
Diesel (reduced in D) & 1.3 & 0.5 & 0.4 \\
Biomass burning in 2000 & 3.1 & 24 & 7.7 \\
Biomass burning in 1750 & 1.0 & 9 & 9 \\
Year 2000 total particulate (PD) & 7.7 & 32.9 & 6.1 \\
Year 1750 total particulate (PI) & 1.4 & 9.7 & 17 \\
\hline
\end{tabular}

indirect effect response to all aerosols in ten global models, and compared these responses to satellite retrievals. The study indicated a positive relation between cloud droplet number concentration (CDNC) and aerosol optical depth (AOD) that was generally well captured by the models. The models generally overestimated a positive relation between cloud liquid water path (LWP) and AOD, suggesting possible deficiencies in their cloud water conversion to rain, or autoconversion parameterizations. On the other hand, the models generally underestimated the positive relation between cloud cover (CC) and AOD. The modeled global mean cloudy sky forcing due to all aerosols, scaled to the satellite CDNCAOD regression slopes, was $-1.2 \pm 0.4 \mathrm{Wm}^{-2}$.

\section{Experimental design}

\subsection{Experiments}

The model experiments for the full year 2000 and preindustrial are as defined in Quaas et al. (2009). All of the models participated in the Quaas et al. (2009) experiments, however many of them have evolved since.

Six models performed the three soot-reduction experiments. The models' analyses were based on five-year experiments, following one year of spin-up (four months for CAM-Oslo). Climatological sea-surface temperatures were prescribed, so that spin-up was only needed for the aerosol concentrations, and several months is sufficient for this. Table 1 provides the $\mathrm{BC}$ and $\mathrm{OC}$ emissions for each experiment. The first (FF) reduced all fossil-fuel $\mathrm{BC}$ and is therefore an idealized experiment of an extreme impact of $\mathrm{BC}$ on indirect effects. The second $(\mathrm{BF})$ reduced all biofuel $\mathrm{BC}$ and $\mathrm{OC}$ and is also idealized especially because it is a particularly large reduction; however it is more realistic because biofuel $\mathrm{BC}$ and $\mathrm{OC}$ are typically co-emitted. The third (D) reduced diesel $\mathrm{BC}$ and $\mathrm{OC}$. The $\mathrm{OC}$ to $\mathrm{BC}$ ratio is 4 and 0.4 for the biofuel and diesel emissions, respectively. The emissions are from Dentener et al. (2006), including carbona-

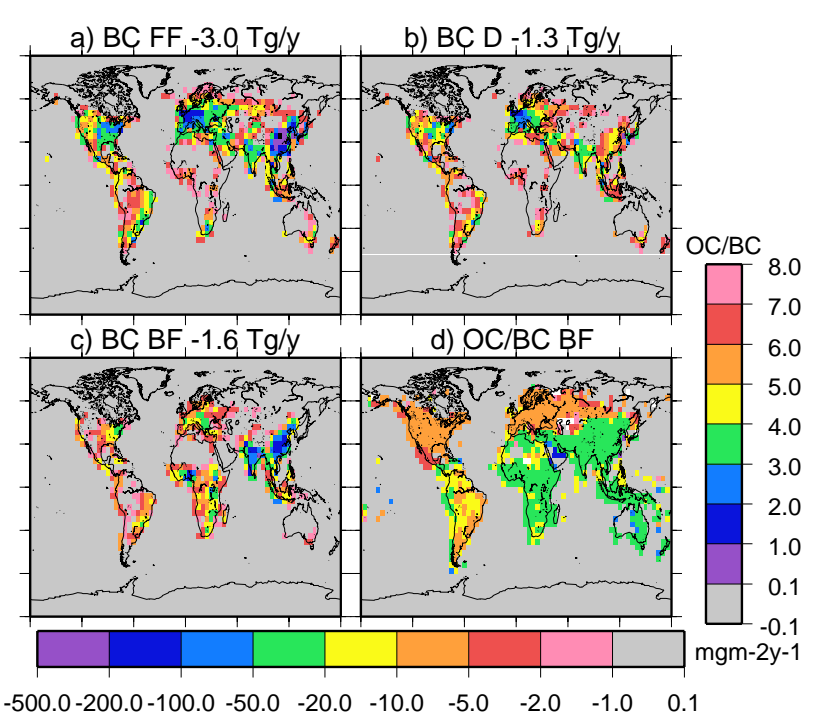

Fig. 1. Emission reductions for the three experiments (scale below): (a) fossil fuel BC, (b) Diesel BC, (c) Biofuel BC and (d) the ratio $\mathrm{OC} / \mathrm{BC}$ that is reduced in the biofuel experiment (scale on side).

ceous aerosol pollution emissions from an updated version of Bond et al. (2004). Other aerosol species emissions that are unchanged in the experiments include sulfur $\left(145 \mathrm{Tg} \mathrm{Sy}^{-1}\right.$ for 2000 and $34 \mathrm{Tg} \mathrm{Sy}^{-1}$ for 1750$)$, dust $\left(1680 \mathrm{Tg}^{-1}\right)$ and sea-salt $\left(7900 \mathrm{Tg}^{-1}\right)$, with most sulfur emitted as gaseous $\mathrm{SO}_{2}$ that then oxidizes to form sulfate. Most models assume that secondary organic aerosols are emitted as particulate OC $\left(14 \mathrm{Tg} \mathrm{y}^{-1}\right)$; CAM-PNNL includes secondary organic aerosol (SOA) formation from reversible SOA condensation integrated over the size distribution of each mode.

Figure 1 shows the global distributions of the soot emissions reduced for the FF, BF and D experiments. The largest reductions occur for FF in southeast Asia, Europe and eastern North America and for BF in south and southeast Asia and for $\mathrm{D}$ in Europe. Figure 1d has the global distribution of the ratio of $\mathrm{OC}$ to $\mathrm{BC}$ for biofuel. Biofuel $\mathrm{OC} / \mathrm{BC}$ is largest in North America and Europe, followed by South America and then by Asia and Africa. The OC/BC ratio for diesel does not vary as much geographically and is much smaller than for biofuel.

All models saved diagnostics for cloud optical depth, cloud droplet number concentration, liquid and total cloud cover, liquid water path, aerosol optical depth and top-ofatmosphere radiative net forcing and clear-sky forcing (some models provided these only in the short-wave). Some of the models saved CCN, cloud droplet radius, information on ice clouds, cloud albedo and more specific information on aerosol composition. We worked primarily with diagnostics common to the models. 


\subsection{Models}

The six global models had aerosol schemes that resolved particle number, hygroscopicity and aerosol cloud indirect effects. The model cloud and aerosol microphysical schemes are summarized in Tables 2 and 3.

All models simulate stratiform and convective clouds. All models applied indirect effects to stratiform clouds with three models also including convective indirect effects, GISS, LSCE and SPRINTARS (for cloud albedo effect only). All models except CAM-PNNL and CAM-Oslo assumed a lower limit to their cloud droplet number concentration in order to avoid very small values under clean conditions which would then cause very large radiative effects. In all models, aerosols are taken into cloud droplets during cloud formation and then rained out following autoconversion; aerosols are also scavenged by falling rain below-cloud.

The top-of-atmosphere (TOA) radiative flux changes result from a combination of changes in cloud lifetime, cloud albedo, and cloud response to the soot absorption and direct aerosol forcing above cloud. The radiative effects resulting from interstitial treatment of $\mathrm{BC}$ within clouds is included in some models however BC within cloud droplets is not included in these models. The latter effect was estimated to enhance $\mathrm{BC}$ absorption by about 5\% according Chuang et al. (2002). Jacobson (2006) found that surface warming by $\mathrm{BC}$ was enhanced about $10 \%$ due to $\mathrm{BC}$ inclusions in both cloud liquid droplets and ice particles. Note that the radiative flux changes resulting from the cloud changes are not strictly climate forcings, because the cloud changes include fast responses and feedbacks of the climate system.

Four of the models, CAM-Oslo, CAM-PNNL, ECHAM5 and GISS, have detailed microphysical schemes in which carbonaceous particle hygroscopicity depends upon mixing with more hygroscopic species, including deposition of sulfuric (all four models) or nitric acids (GISS), secondary organics (CAM-PNNL), or coagulation with other aerosol species (all four models). These four also include particle nucleation schemes. The other two, LSCE and SPRINTARS, have hygroscopity that is fixed or time-dependent. Most of the models assume larger biofuel than fossil fuel particle size upon emission, however a variety of sizes are assumed. There is some disparity in assumption about OC hygroscopicity among the models (Table 3), with emitted hygroscopicity ranging from 0 to $70 \%$. We note that low hygroscopicity is generally appropriate for fossil fuels while higher values are appropriate for most biofuels. All models except the LSCE and ECHAM5 model (see below) use Köhler theory to determine particle activation, in which $\mathrm{CCN}$ activation depends on particle size, chemical properties, and cloud updraft velocity. We now provide some more detail for each model aerosol microphysical scheme.

CAM-Oslo (CO) uses the NCAR CAM3 global model. The model aerosol microphysics is described by Seland et al. (2008) and the aerosol indirect effects by Hoose et al. (2009). The aerosol population includes 16 process modes and 44 size bins with process-determined mixing states. Processes include nucleation, coagulation, condensation and deposition. Emitted fossil fuel $\mathrm{BC}$ and $\mathrm{OC}$ are assumed to be externally mixed, while biofuel $\mathrm{BC}$ and $\mathrm{OC}$ are assumed internally mixed. Externally mixed $\mathrm{BC}$ is hydrophobic and OC is $25 \%$ as hygroscopic as sulfate. Particles become hydrophilic through sulfate condensation or by coagulation with sulfate or seasalt. Hygroscopicity of the mixed particles is determined by the volume mixing ratio of the species.

CAM-PNNL (CP) uses the NCAR CAM model with a 7 mode modal aerosol scheme (MAM-7) (Easter et al., 2004). Primary organic and black carbon are emitted into a primary carbon mode, which ages to a mixed accumulation mode by condensation of sulfate, ammonia or secondary organics or by coagulation with other accumulation mode particles. The model emits condensable secondary organic aerosol gas (SOAG), predicts SOAG in the model and the partition of SOAG to aerosol phase to form SOA. Boundary layer nucleation is included in the aerosol scheme.

ECHAM5 (E) uses the ECHAM5-HAM model (Stier et al., 2005) with the indirect effects described by Lohmann and Hoose (2009). Cloud droplet activation is based on Köhler theory, but is simplied such that it only depends on particle size and cloud updraft velocity, while the chemical properties are neglected (Lin and Leatch, 1997; Lohmann et al., 2007). The activation thresholds are $35 \mathrm{~nm}$ and $25 \mathrm{~nm}$ for particles activating in stratiform and detraining convective clouds, respectively. $\mathrm{BC}$ and $35 \% \mathrm{OC}$ are emitted into an insoluble mode and $65 \%$ OC is emitted into a soluble mode. The insoluble mode transfers to soluble as coagulation and deposition renders it hygroscopic.

GISS-MATRIX (G) uses the GISS ModelE GCM, with the MATRIX aerosol microphysical scheme (Bauer et al., 2008, 2010) and aerosol indirect effects (Bauer et al., 2010). The microphysical scheme uses method of moments and BC and OC may exist in 8 possible "populations". Fossil and biofuel $\mathrm{BC}$ is emitted into $\mathrm{BC} 1$ (with less than $5 \%$ acids) and OC into OCC. As BC1 ages, condensation of sulfate, nitrate or water moves it to $\mathrm{BC} 2$ (5-20\% inorganics) and then to BC3 (>20\% inorganics); coagulation with sulfate moves it to BCS, with dust to DBC, with OC to OCB and with seasalt to MXX. OCC coagulation with BC moves it to BOC and with other species to MXX. The hygroscopic fraction is set to 0 for $\mathrm{BC} 1$ and $\mathrm{DBC}, 0.5$ for BOC, 0.7 for OCC and 1 for all other populations with carbonaceous components.

LSCE (L) uses the LMDZ GCM with the INCA aerosol scheme. The INCA scheme represents aerosols in five separate modes that are either insoluble or soluble. Eighty percent of BC and 50\% of OC are emitted as insoluble; as these aerosols age, they become hygroscopic with a half-life of 1.1 day. The CDNC is based on aerosol mass according to the relationships inferred from MODIS retrievals (Quaas et al., 2009). 
Table 2. Model and cloud microphysical information.

\begin{tabular}{|c|c|c|c|c|c|c|}
\hline Model & $\begin{array}{l}\text { Resolution grid } \\
\text { number (longi- } \\
\text { tude } \times \text { latitude } \\
\times \text { layer) }\end{array}$ & $\begin{array}{l}\text { Cloud } \\
\text { microphysical } \\
\text { scheme }\end{array}$ & $\begin{array}{l}\text { Cloud drop } \\
\text { nucleation } \\
\text { scheme }\end{array}$ & $\begin{array}{l}\text { Autoconversion } \\
\text { parameteriza- } \\
\text { tion }\end{array}$ & $\begin{array}{l}\text { Minimum } \\
\text { CDNC value } \\
\mathrm{cm}^{-3}\end{array}$ & $\begin{array}{l}\text { Indirect Effects } \\
\text { included \# }\end{array}$ \\
\hline $\begin{array}{l}\text { CAM-Oslo } \\
\text { (CO) }\end{array}$ & $128 \times 64 \times 26$ & $\begin{array}{l}\text { Two moment } \\
\text { warm cloud: } \\
\text { Storelvmo et } \\
\text { al. (2006); } \\
\text { Hoose et } \\
\text { al. (2009) }\end{array}$ & $\begin{array}{l}\text { Abdul-Razzak } \\
\text { and Ghan } \\
(2000)\end{array}$ & $\begin{array}{l}\text { Rasch and } \\
\text { Kristjansson } \\
\text { (1998) }\end{array}$ & none & $\mathrm{S} 1, \mathrm{~S} 2$ \\
\hline $\begin{array}{l}\text { CAM } \\
\text { PNNL (CP) }\end{array}$ & $144 \times 96 \times 30$ & $\begin{array}{l}\text { Two-moment: } \\
\text { Morrison and } \\
\text { Gettelman } \\
(2008)\end{array}$ & $\begin{array}{l}\text { Abdul-Razzak } \\
\text { and Ghan } \\
(2000)\end{array}$ & $\begin{array}{l}\text { Khairoutdinov } \\
\text { and Kogan } \\
(2000)\end{array}$ & none & $\mathrm{S} 1, \mathrm{~S} 2$ \\
\hline $\begin{array}{l}\text { ECHAM5 } \\
\text { (E) }\end{array}$ & $128 \times 64 \times 19$ & $\begin{array}{l}\text { Two-moment } \\
\text { liquid \& ice: } \\
\text { Lohmann et } \\
\text { al. (2007) }\end{array}$ & $\begin{array}{l}\text { Lin and Leaitch } \\
\text { (1997) }\end{array}$ & $\begin{array}{l}\text { Khairoutinov } \\
\text { and Kogan } \\
(2000)\end{array}$ & 40 & $\mathrm{~S} 1, \mathrm{~S} 2$ \\
\hline GISS (G) & $72 \times 46 \times 20$ & $\begin{array}{l}\text { Two-moment: } \\
\text { Morrison and } \\
\text { Gettelman } \\
(2008)\end{array}$ & $\begin{array}{l}\text { Lohmann et } \\
\text { al. (2007) }\end{array}$ & $\begin{array}{l}\text { Rotstayn and } \\
\text { Liu (2005) }\end{array}$ & 20 & $\mathrm{~S} 1, \mathrm{~S} 2, \mathrm{C} 1, \mathrm{C} 2$ \\
\hline $\operatorname{LSCE}(\mathrm{L})$ & $97 \times 73 \times 19$ & $\begin{array}{l}\text { PDF for cloud } \\
\text { cover, water } \\
\text { content (Bony } \\
\text { and Emanuel, } \\
\text { 2001) }\end{array}$ & N/A & $\begin{array}{l}\text { Depends on } \\
\text { cloud water } \\
\text { content (no } 2 \text { nd } \\
\text { indirect effect) }\end{array}$ & 20 & $\mathrm{~S} 1, \mathrm{C} 1$ \\
\hline $\begin{array}{l}\text { SPRINTARS } \\
\text { (S) }\end{array}$ & $320 \times 160 \times 56$ & $\begin{array}{l}\text { Two-moment } \\
\text { for liquid and } \\
\text { ice clouds }\end{array}$ & $\begin{array}{l}\text { Abdul-Razzak } \\
\text { and Ghan } \\
(2000)\end{array}$ & Berry (1967) & 25 & $\mathrm{~S} 1, \mathrm{~S} 2, \mathrm{C} 1, \mathrm{C} 2$ \\
\hline
\end{tabular}

\# $\mathrm{S}=$ stratiform, $\mathrm{C}=$ convective, $1=$ cloud albedo (1st indirect), 2 = cloud lifetime $(2 \mathrm{nd}$ indirect).

SPRINTARS (S) uses the MIROC GCM. Fossil fuel BC is assumed to be $50 \%$ externally mixed and the rest is mixed with OC. Biofuel BC and OC are assumed to be co-emitted. $\mathrm{BC}$ mode radius is $0.0118 \mathrm{um}$ and dry mixed $\mathrm{BC} / \mathrm{OC}$ is 0.1 um but grows to 0.2 and 0.3 as relative humidity increases to $95 \%$ and $98 \%$. The hygroscopicity is $5 \times 10^{-7}$ for BC and 0.14 for OC.

\section{Results}

\subsection{Impacts on cloud droplet number concentration, liquid water path and cloud optical depth}

The cloud radiative flux response to aerosol changes results from changes in cloud droplet number concentration (CDNC) which in turn affects the cloud optical depth (COD) and albedo (cloud albedo effect) and cloud cover (cloud lifetime effect). Typically the COD is proportional to the liquid water path (LWP) and inversely proportional to the droplet effective radius. The effective radius decreases as CDNC increases, and the COD increases with LWP and CDNC. Figures 2, 3 and 4 show the changes in CDNC, LWP and COD from the carbonaceous aerosol reduction experiments. COD changes, where systematically due to aerosol perturbations, result mostly from changes in CDNC and LWP. Table 4 has the changes in COD, LWP and CDNC for the reduction experients, as well as the difference between pre-industrial and year 2000, or the impact of reducing all pollution.

The impact of LWP and CDNC changes on COD are apparent from comparing Figs. 2, 3 and 4, which in most cases are highly correlated. Many of the models have relatively stronger LWP changes over ocean and stronger CDNC changes over land, with the CDNC changes dominating in influence on COD. The geographical distributions of COD reduction are quite diverse among the models, in part due to differing wavelength responses and model resolutions. 
Table 3. Model soot microphysical characteristics.

\begin{tabular}{|c|c|c|c|c|c|c|c|}
\hline Model & $\begin{array}{l}\text { Volume } \\
\text { mean } \\
\text { radius of } \\
\text { emitted } \\
\text { FF BC } \\
(\mu \mathrm{m})^{\mathrm{a}}\end{array}$ & $\begin{array}{l}\text { Volume } \\
\text { mean } \\
\text { radius of } \\
\text { emitted } \\
\mathrm{BF} \quad \mathrm{BC}, \\
\mathrm{OC}(\mu \mathrm{m})\end{array}$ & $\begin{array}{l}\mathrm{FF} \text { or } \mathrm{BF} \\
\mathrm{BC} \text { and } \\
\mathrm{OC} \text { co- } \\
\text { emitted in } \\
\text { single } \\
\text { particle }\end{array}$ & $\begin{array}{l}\text { Hygroscopicity and } \\
\text { how determined for BC } \\
\text { and OC }\end{array}$ & $\begin{array}{l}\text { Effects } \\
\text { included }^{b}\end{array}$ & $\begin{array}{l}\text { Nucleation } \\
\text { schemes } \\
\text { included }^{\mathrm{c}}\end{array}$ & Publications \\
\hline $\begin{array}{l}\text { CAM-Oslo } \\
\text { (CO) }\end{array}$ & $\begin{array}{l}0.0198, \\
10 \% \\
0.139\end{array}$ is & 0.0672 & BF only & $\begin{array}{l}\text { When emitted, OC is } \\
25 \% \text { as hygroscopic as } \\
\text { sulfate, BC is nonhy- } \\
\text { groscopic; mixing with } \\
\text { sulfate or sea-salt in- } \\
\text { creases hygroscopicity. }\end{array}$ & $1,2,3$ & 1 & $\begin{array}{l}\text { Seland et } \\
\text { al. (2008); Hoose } \\
\text { et al. (2009) }\end{array}$ \\
\hline $\begin{array}{l}\text { CAM PNNL } \\
(\mathrm{CP})\end{array}$ & 0.067 & 0.067 & Yes & $\begin{array}{l}\mathrm{OC}, \mathrm{BC} \text { emitted as non- } \\
\text { hygroscopic, age from } \\
\text { mixing. }\end{array}$ & $1,2,3$ & 1,2 & $\begin{array}{l}\text { Easter et } \\
\text { al. (2004) }\end{array}$ \\
\hline $\begin{array}{l}\text { ECHAM5 } \\
\text { (E) }\end{array}$ & 0.0372 & 0.0372 & Yes & $\begin{array}{l}65 \% \text { OC and } 0 \% \text { BC } \\
\text { emitted as hygroscopic, } \\
\text { mixing increases hy- } \\
\text { groscopicity. }\end{array}$ & $1,2,3,4$ & 1,2 & $\begin{array}{l}\text { Stier et al. (2005); } \\
\text { Lohmann and } \\
\text { Hoose (2009) }\end{array}$ \\
\hline GISS (G) & 0.025 & 0.05 & No & $\begin{array}{l}70 \% \text { OC and } 0 \% \text { BC } \\
\text { emitted as hygroscopic, } \\
\text { mixing increases hy- } \\
\text { groscopicity }\end{array}$ & $1,2,3$ & 1 & $\begin{array}{l}\text { Bauer et al. (2008, } \\
2010)\end{array}$ \\
\hline LSCE (L) & 0.08 & 0.19 & No & $\begin{array}{l}80 \% \text { BC and } 50 \% \\
\text { OC emitted as non- } \\
\text { hygroscopic. Aging to } \\
\text { hygroscopic with } 1.1 \\
\text { day half-life }\end{array}$ & 1,3 & & $\begin{array}{l}\text { Balkanski et } \\
\text { al. }(2010)\end{array}$ \\
\hline $\begin{array}{l}\text { SPRINTARS } \\
\text { (S) }\end{array}$ & 0.0499 & 0.704 & $\begin{array}{l}50 \% \text { FF } \\
\mathrm{BC} \text { and } \\
\text { all } \mathrm{BF}\end{array}$ & $\begin{array}{l}5 \times 10^{-7} \text { BC and } 0.14 \\
\text { OC are hygroscopic }\end{array}$ & $1,2,3$ & & $\begin{array}{l}\text { Takemura et } \\
\text { al. (2005) }\end{array}$ \\
\hline
\end{tabular}

a $(\text { volume-mean radius })^{3}=($ mass emissions $) /[($ number emissions $) \times$ density $\times(4 \pi / 3)]$;

b effects: 1 Cloud albedo effect, 2 Cloud lifetime effect, 3 semi-direct effect, 4 mixed-phase cloud effects;

c 1 = binary sulfate-water or ternary sulfate-nitrate-water homogeneous, 2 = boundary layer.

However, in most (17 out of 24) cases, the aerosol reduction experiments result in decreased COD and in most of these cases these changes are related to decreased particle number and CDNC. The CP, S and L models all have decreased CDNC and COD for all experiments (except the L BF experiment with small increase in CDNC).

However for the models that include particle nucleation, deposition and coagulation, reduction of carbonaceous primary aerosols can result in increased viable $\mathrm{CCN}$. For two models that saved $\mathrm{CCN}$ diagnostics ( $\mathrm{CP}$ and $\mathrm{CO}$ ), the $\mathrm{CCN}$ changes were distributed similarly to the CDNC changes, with increased $\mathrm{CCN}$ in some regions and decreased $\mathrm{CCN}$ in others (not shown). The increased CCN from soot reduction results from the liberated secondary species such as sulfuric acid that would have deposited on the soot, but may now either nucleate new particles or deposit on other particles that can form $\mathrm{CCN}$ more readily than the original sootsulfate mixture would have. The $\mathrm{CO}$ and $\mathrm{G}$ models had increased sulfate distributed over their $\mathrm{CCN}$ in the FF experiment (not shown). For the $\mathrm{G}$ model $\mathrm{FF}$ experiment, sulfate deposited on other particles instead of BC, mostly on OC, and the OC-sulfate mixtures made better $\mathrm{CCN}$ than the $\mathrm{BC}$ sulfate particles did. This occurs both because the $\mathrm{OC}$ are larger and more hygroscopic. These highly hygroscopic particles grow and activate more readily than the carbonaceous aerosols would, so that the CDNC and COD can increase. This impact, of soot reduction enhancing $\mathrm{CCN}$, is more likely to occur for $\mathrm{BC}$ reduction than $\mathrm{OC}$, because $\mathrm{BC}$ is assumed to have lower hygroscopicity and/or smaller size. For example, in $\mathrm{G}$ model FF and D experiments, the CDNC and COD both 


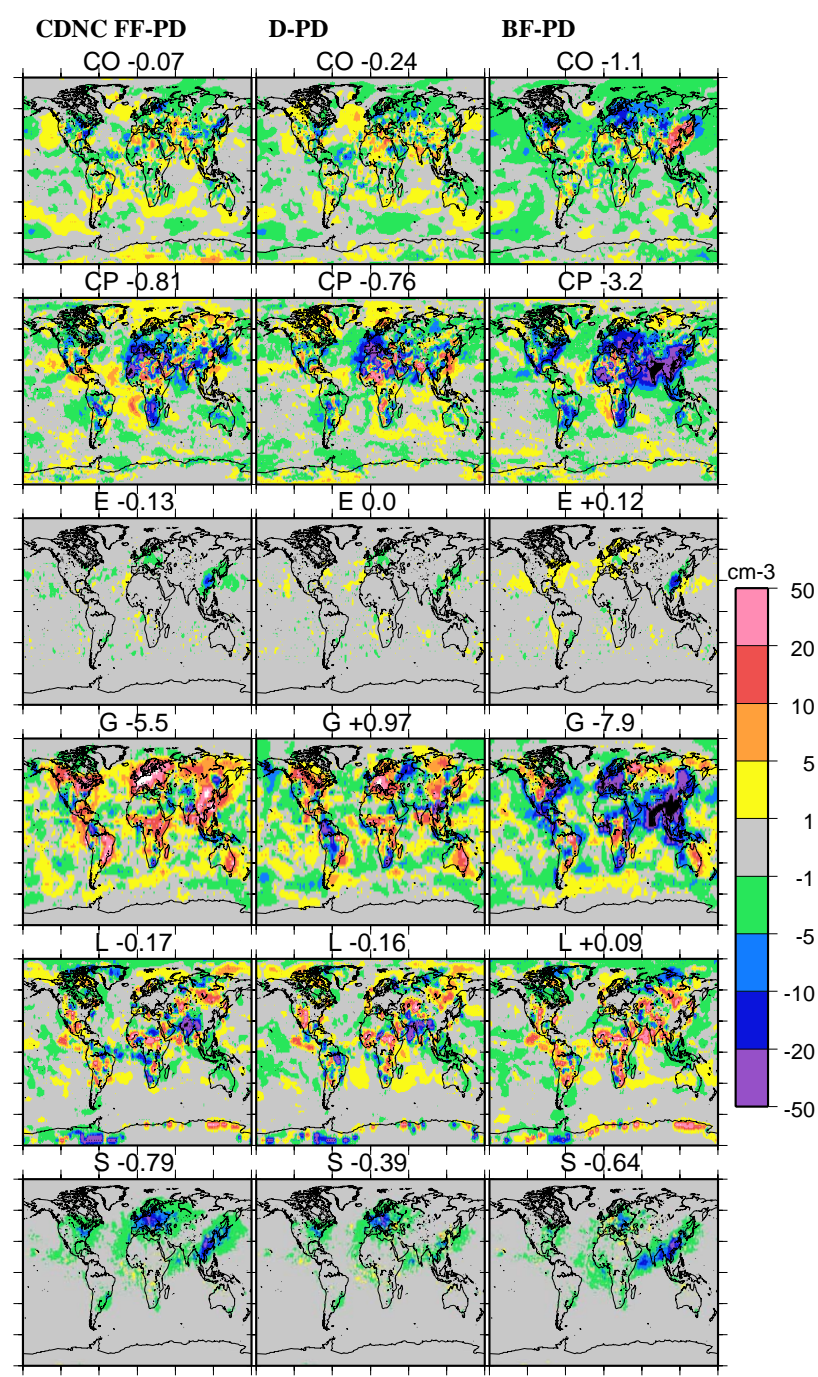

Fig. 2. Difference in annual mean cloud droplet number concentration (CDNC) between the fossil fuel (left), diesel (middle) and biofuel (right) reduction experiments and the full simulation. Each row is one model.

increase. For $\mathrm{CO}$ model $\mathrm{FF}$ and $\mathrm{D}$ experiments, the CDNC decreases less than for $\mathrm{BF}$, and the COD increases. For $\mathrm{CP}$ model FF and D experiments the CDNC and COD decrease less than for BF. All three of these models include nucleation schemes and particle mixing.

In addition to hygroscopicity changes from the carbonaceous aerosol emissions, size also plays an important role in the COD response. The simulations for models with nucleation schemes that have small emitted soot particles sizes, radius $\leq 0.04 \mu \mathrm{m}$ (CO FF, E FF and BF, G FF; see Table 3) all have a positive COD change. Apparently the production of viable $\mathrm{CCN}$ is greater when there are fewer small particles competing for condensation of $\mathrm{H}_{2} \mathrm{SO}_{4}$ and other precursors.

Because of the competition between primary particle loss and shift toward more hygroscopic particle population, it be-

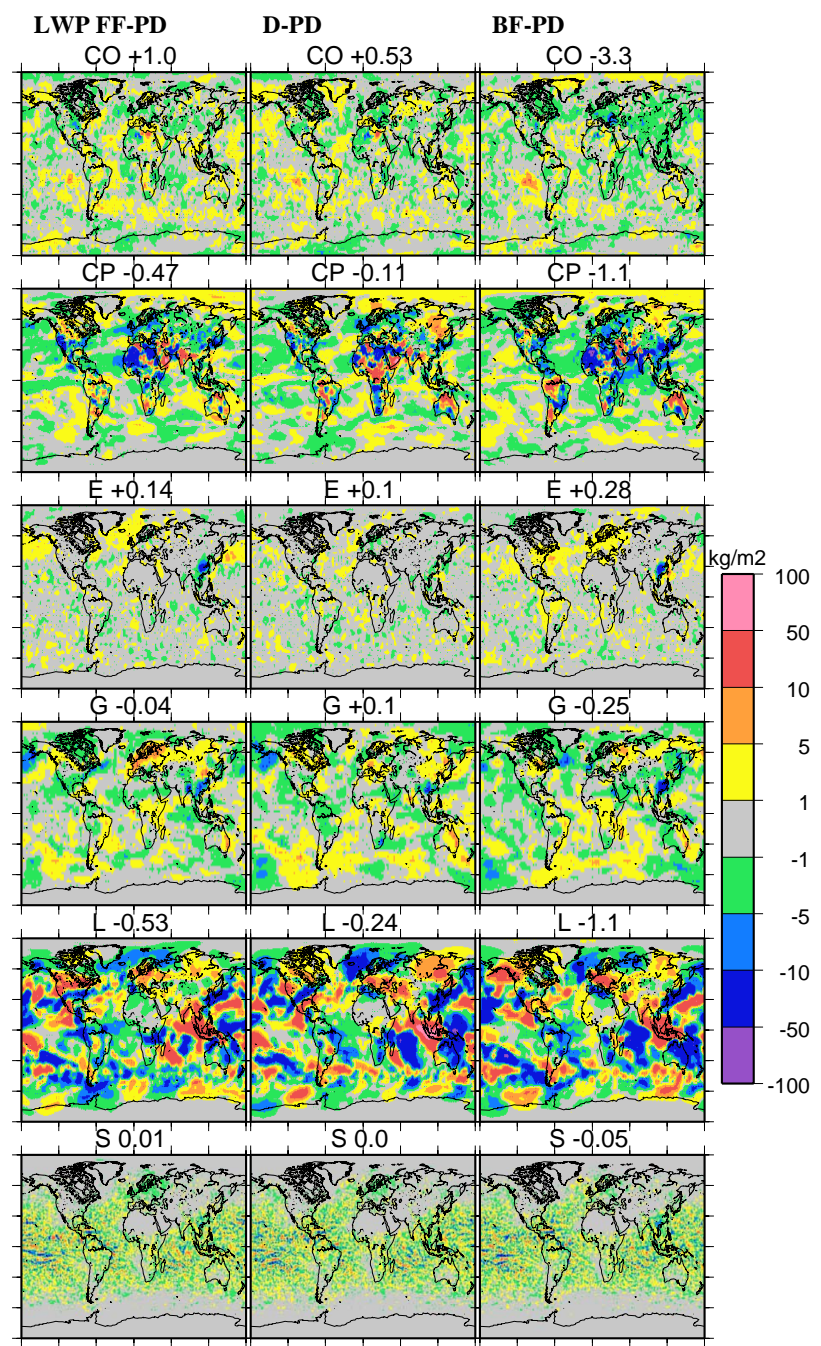

Fig. 3. Difference in annual mean liquid water path (LWP) between the fossil fuel (left), diesel (middle) and biofuel (right) reduction experiments and the full simulation. Each row is one model. The $\mathrm{CO}$ model fields are reduced by a factor of 10 to plot on same color scale.

comes difficult to discern clear geographical patterns in COD change (Fig. 4). However nearly all models have large reductions in CDNC and COD for the BF reduction experiment over Asia where the soot reductions are large (Fig. 1c). The $\mathrm{S}$ model has clear correlations between COD reductions and aerosol emission reductions, however this model does not have aerosol nucleation effects competing with soot particle reduction effects.

More than half of the experiments have stronger COD and CDNC signals in the Northern (NH, given in parentheses in Table 4) than Southern Hemisphere ( $\mathrm{SH})$, which is expected because the emissions are greater in the north. On the other hand, the SH may have more sensitivity to small pollution reductions because it is typically cleaner. 
Table 4. Global mean (NH mean) model cloud responses due to reductions of fossil fuel (FF), diesel (D) and biofuel (BF) soot (BF), and all pollution (PI).

\begin{tabular}{|c|c|c|c|c|c|c|}
\hline & $\triangle \mathrm{CDNC}$ & $\Delta \mathrm{LWP}$ & $\triangle \mathrm{COD}$ & $\Delta \mathrm{CC}$ & $\Delta F \mathrm{Net}$ & $\Delta F$ cloudy \\
\hline \multicolumn{7}{|c|}{ CAM-Oslo } \\
\hline FF & $-0.07(-0.36)$ & 1.0 & $0.25(0.10)$ & $0.09(0.14)$ & -0.18 & $-0.21(-0.40)$ \\
\hline $\mathrm{D}$ & $-0.24(-0.15)$ & 0.53 & $0.18(0.07)$ & $-0.04(0.0)$ & 0.04 & $0.006(0.02)$ \\
\hline $\mathrm{BF}$ & $-1.1(-1.3)$ & -3.3 & $-0.43(-0.92)$ & $0.09(0.24)$ & 0.13 & $0.16(0.16)$ \\
\hline PI & $-8.4(-11.6)$ & -24 & $-3.3(-4.6)$ & $-0.01(0.06)$ & 1.9 & $2.0(2.5)$ \\
\hline \multicolumn{7}{|c|}{ CAM-PNNL } \\
\hline $\mathrm{FF}$ & $-0.81(-0.99)$ & -0.47 & $-0.04(-0.14)$ & $-0.06(-0.09)$ & -0.05 & $0.03(0.09)$ \\
\hline $\mathrm{D}$ & $-0.76(-1.0)$ & -0.11 & $-0.06(-0.09)$ & $-0.04(-0.09)$ & 0.04 & $0.06(0.18)$ \\
\hline $\mathrm{BF}$ & $-3.2(-5.3)$ & -1.1 & $-0.22(-0.43)$ & $-0.05(-0.08)$ & -0.03 & $0.13(0.22)$ \\
\hline PI & $-27.8(-43.2)$ & -7.7 & $-1.4(-2.1)$ & $-0.91(-1.6)$ & 1.8 & $1.4(2.1)$ \\
\hline \multicolumn{7}{|c|}{ ECHAM5 } \\
\hline $\mathrm{FF}$ & $-0.19(-0.15)$ & 0.14 & $5.1(-0.52)$ & $0.0(0.01)$ & -0.17 & $-0.12(0.18)$ \\
\hline $\mathrm{D}$ & $-0.06(-0.1)$ & 0.10 & $6.6(3.4)$ & $0.02(-0.01)$ & -0.12 & $-0.03(-0.01)$ \\
\hline $\mathrm{BF}$ & $0.01(-0.06)$ & 0.28 & $3.4(0.36)$ & $-0.06(-0.2)$ & 0.05 & $-0.08(-0.36)$ \\
\hline PI & $-3.0(-1.2)$ & -6.0 & $-7.7(-2.1)$ & $-0.27(-0.11)$ & 1.4 & $0.36(0.08)$ \\
\hline \multicolumn{7}{|c|}{ GISS } \\
\hline $\mathrm{FF}$ & $2.7(4.3)$ & -0.04 & $0.02(-0.28)$ & $-0.08(-0.22)$ & -0.19 & $-0.04(0.03)()$ \\
\hline $\mathrm{D}$ & $0.48(0.78)$ & 0.10 & $0.05(0.06)$ & $-0.04(-0.17)$ & -0.10 & $-0.05(0.03)$ \\
\hline $\mathrm{BF}$ & $-4.0(-7.2)$ & -0.25 & $-0.05(-0.08)$ & $-0.16(-0.26)$ & 0.12 & $0.20(0.10)$ \\
\hline PI & $-24.6(-40.9)$ & -0.70 & $-0.38(-0.66)$ & $-0.30(-0.30)$ & 0.56 & $0.45(0.42)$ \\
\hline \multicolumn{7}{|c|}{ LSCE } \\
\hline $\mathrm{FF}$ & $-0.17(-0.17)$ & -0.53 & $-0.10(-0.16)$ & $-0.20(-0.12)$ & -0.01 & $-0.15(-0.21)$ \\
\hline $\mathrm{D}$ & $-0.16(-0.29)$ & -0.24 & $-0.02(-0.06)$ & $-0.37(-0.21)$ & 0.08 & $-0.18(-0.43)$ \\
\hline $\mathrm{BF}$ & $0.09(-0.05)$ & -1.1 & $-0.12(-0.33)$ & $-0.29(-0.02)$ & 0.0 & $0.18(0.16)$ \\
\hline PI & $-4.2(-1.7)$ & -0.15 & $-0.46(-0.25)$ & $-0.25(-0.18)$ & 0.41 & $0.47(0.15)$ \\
\hline \multicolumn{7}{|c|}{ SPRINTARS } \\
\hline $\mathrm{FF}$ & $-0.79(-0.15)$ & 0.01 & $-0.04(-0.01)$ & $-0.01(0.0)$ & 0.0 & $0.004(-0.01)$ \\
\hline $\mathrm{D}$ & $-0.38(-0.07)$ & 0.0 & $-0.02(0.0)$ & $-0.01(0.0)$ & 0.01 & $0.01(-0.01)$ \\
\hline $\mathrm{BF}$ & $-0.63(-0.19)$ & -0.05 & $-0.04(-0.01)$ & $-0.01(0.0)$ & 0.06 & $0.04(0.02)$ \\
\hline PI & $-7.4(-3.1)$ & -0.74 & $-0.56(-0.21)$ & $-0.14(-0.01)$ & 1.0 & $0.79(0.34)$ \\
\hline
\end{tabular}

$\mathrm{CDNC}=$ cloud droplet number concentration, $\# \mathrm{~cm}^{-3}$, is for top of cloud for all models except GISS which is average over cloud depth. COD $=$ cloud optical depth. $\mathrm{CC}=$ cloud cover $\%$, in all cases this is liquid cloud only except ECHAM5 is low cloud. $\Delta F$ Net is the net change in TOA radiative flux, Wm ${ }^{-2} ; \Delta F$ cloudy is the TOA flux change in the cloudy sky, $\mathrm{Wm}^{-2}$; LSCE and ECHAM5 models use short-wave flux only.

\subsection{Impacts on cloud cover}

For models that include the aerosol cloud lifetime effect (all except L), meaning they allow the conversion of cloud droplets to rainwater to depend upon the aerosols, the cloud cover (CC) can change due to the aerosol microphysical changes. All models also include semi-direct effects, or the change in cloud distribution resulting from aerosol direct radiative perturbation of the atmospheric thermal structure (e.g. Hansen et al., 1997; Koch and Del Genio, 2010). The models include radiative interactions among $\mathrm{BC}$ and cloud particles within a cloud, but do not account for the effects of absorption enhancement of BC within cloud droplets as described and treated in Jacobson $(2002,2006)$. Scattering between cloud and aerosol layers are typically included. Therefore cloud cover changes in the experiments due to both the lifetime and semi-direct effects.

For most experiments (20 out of 24), aerosol reduction also decreases cloud cover (CC, shown in Fig. 5). For cases that had increased COD due to reduced soot (see previous section, Fig. 4) we might also expect increased cloud cover. However the semi-direct effect is often negative in global 


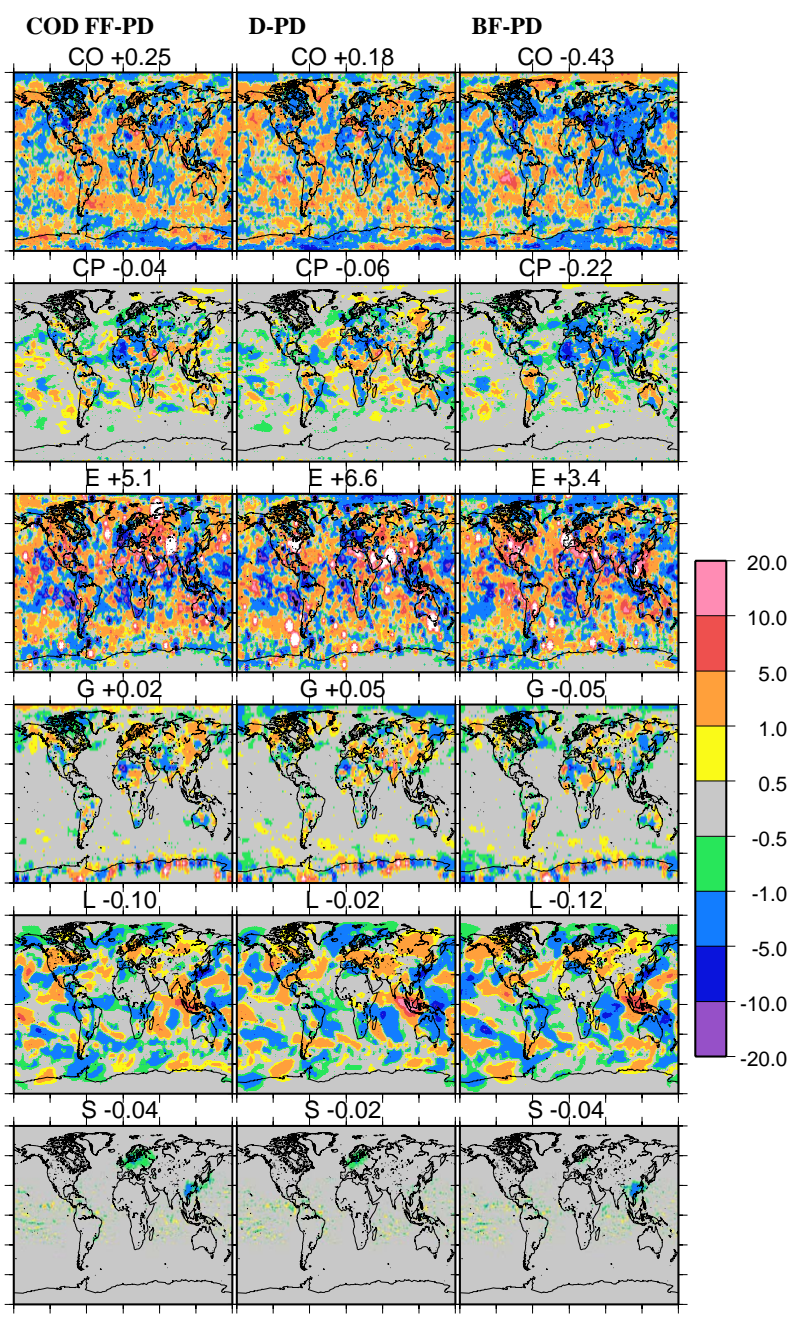

Fig. 4. Difference in annual mean cloud optical depth (COD) between the fossil fuel (left), diesel (middle) and biofuel (right) reduction experiments and the full simulation. Each row is one model.

models (Koch and Del Genio, 2010), meaning that reduction in absorbing aerosols also decreases cloud cover. This effect is most potent for strongly absorbing aerosols (e.g. the FF, D experiments). Therefore, for example, the $\mathrm{G}$ model cases FF and D have decreased CC even though the COD increases. On the other hand the $\mathrm{CO}$ model has increased $\mathrm{CC}$ for FF, and for BF even though COD, CDNC and LWP decrease, so that this model may have a positive semi-direct effect especially noticable over the continents (Fig. 5). Most of the FF experiments have decreased CC in the Arctic, a remote region where the strongly absorbing $\mathrm{BC}$ would tend to be above cloud. Soot above stratocumulus clouds can have a semi-direct cloud cover enhancement (Koch and Del Genio, 2010), so that soot removal in this region could cause CC reduction.
Table 5. Correlation coefficients between $\mathrm{CC}$ and COD changes from PD and each experiment.

\begin{tabular}{lrrr}
\hline Model & BF & FF & D \\
\hline CO & -0.99 & 0.99 & -0.96 \\
CP & 0.98 & 0.97 & 0.96 \\
E & -0.86 & -0.57 & 0.82 \\
G & 0.98 & 0.91 & 0.59 \\
L & 0.99 & 0.95 & 0.25 \\
S & 0.87 & -0.41 & -0.76 \\
\hline
\end{tabular}

The regional patterns of CC change in individual models tend to be similar for their three experiments. For example, $\mathrm{CO}$ (first row of Fig. 5) has increased CC over Europe and the north Atlantic in all experiments but reduced $\mathrm{CC}$ to the south of these regions. CP (2nd row) has increased CC in the Arctic but decreased CC over Europe and the Atlantic. Model L (5th row) also has reduced CC over much of Europe and the North Pacific but increased CC over northwestern North America and northeastern Eurasia. Therefore it appears that the model cloud responses have a characteristic dynamical and/or semi-direct component. The $\mathrm{CC}$ responses are stronger in the $\mathrm{NH}$ than $\mathrm{SH}$ for the $\mathrm{G}, \mathrm{CP}$, two of the $\mathrm{CO}$ and one of the E experiments.

Correlation between the COD (Fig. 4) and CC (Fig. 5) changes are strong in many cases (Table 5), perhaps dominated by regions of strongest changes. The $\mathrm{BF}$ experiment has correlation coefficient $\geq 0.98$ for three models; the $\mathrm{CO}$ model has very strong anti-correlation, -0.99 . Most models also have fairly strong and positive correlation for FF. For the $\mathrm{D}$ experiment the correlations are weaker.

\subsection{Cloudy-sky radiative effects}

Figure 6 shows the TOA radiative flux changes in the cloudy atmosphere from the $\mathrm{BC}$-reduction experiments. This flux change is a combination of cloud lifetime, cloud albedo, cloud response to the soot absorption effects on the thermal structure of the atmosphere, and the direct aerosol forcing above cloud.

Although the magnitude and distribution of the flux changes differ greatly among the models, there are some robust features. The BF experiment radiative effect is positive for all models except $\mathrm{E}$ and is the most positive of the three experiments for each model. The FF experiment response is more diverse among the models, but all models have negative or very small positive responses. The net magnitudes of the responses to the diesel-reduction experiment are generally smaller, less than $\pm 0.06 \mathrm{Wm}^{-2}$, except for the $\mathrm{L}$ model with $-0.18 \mathrm{Wm}^{-2}$. The geographical pattern of flux change for each model are generally similar across the experiments, as we also noted for the cloud cover changes (previous section). 
In general the cloudy-sky radiative flux changes can be explained in terms of the changes in CC (Fig. 5) and in COD (Fig. 4), so that the TOA radiative flux changes are anti-correlated with either or both of these. For example, the $\mathrm{CO}$ and $\mathrm{CP} \mathrm{BF}$ experiment has generally positive flux change over much of Eurasia, due mainly to reduced COD but with some areas (e.g. southern Europe) having negative flux from increased cloud cover. The E model radiative effect is strongly influenced by the changes in CC for all experiments, with increased Arctic CC (negative forcing) but decreased $\mathrm{CC}$ at mid-latitudes of the north and positive radiative effect.

The largest $\mathrm{BC}$ reductions are for FF in Europe and southeast Asia and the BF reductions in southeast Asia (Fig. 1). Most of the models have negative forcing over most of Europe for FF and D. For some of the models $(\mathrm{CO}, \mathrm{CP}, \mathrm{G})$, there is also a tendency to have (more) positive forcing over Eurasia for the BF experiment.

Although there is large diversity in model responses to soot reduction, there is also large diversity in the response of present-day relative to pre-industrial, i.e. for the (PD vs PI) indirect effects generally (Table 4). The cloudy TOA radiative flux change from $\mathrm{PI}$ to $\mathrm{PD}$ ranges from -0.36 to $-2.0 \mathrm{Wm}^{-2}$, about a factor of six, similar to the range given in Quaas et al. $\left(2009,-0.27\right.$ to $-1.9 \mathrm{Wm}^{-2}$ ). The BF to $\mathrm{PD}$ change (now in terms of pollution addition) ranges from -0.20 to $+0.08 \mathrm{Wm}^{-2}$ and the FF to PD from -0.03 to $+0.21 \mathrm{Wm}^{-2}$, each with spread of about $0.25 \mathrm{Wm}^{-2}$ but with the BF more negative. The BF-PD flux change percentage of the PI-PD flux change for each model is $-22,5,8,8,38$, $44 \%$ for E, S, CO, CP, L and G. This can be thought of as the size of the contribution of BF soot to the indirect effect. The two models that did not apply a minimum CDNC constraint, $\mathrm{CO}$ and $\mathrm{CP}$, did have larger PD vs PI response compared with other models, but their soot-reduction responses were not particularly enhanced.

About half of the model simulations have $\mathrm{NH}$ forcing greater than or equal to SH (Table 4). However the order of the bio-diesel-fossil fuel from most to least negative generally remains preserved for $\mathrm{NH}$ as for the global average.

The interannual variability and the resulting standard deviation for the experiments is large. We calculated standard deviation for the changes from $\mathrm{BF}$ to $\mathrm{PD}$ over the five years of simulation in the L, E and G models, the only models that contributed results for individual years. The standard deviation for the TOA radiative flux change was $0.25 \mathrm{Wm}^{-2}$ for $\mathrm{L}, 0.46 \mathrm{Wm}^{-2}$ for $\mathrm{E}$, and $0.05 \mathrm{Wm}^{-2}$ for $\mathrm{G}$ compared to the mean flux changes of $0.18,-0.08$ and $0.20 \mathrm{Wm}^{-2}$ respectively. In the L model, the standard deviations for $\mathrm{CC}$ and COD changes for the BF vs PD were $0.11 \%$ and 0.07 , compared to mean changes of $-0.29 \%$ and -0.12 . In the $\mathrm{E}$ model these standard deviations for CC and COD changes were $0.02 \%$ and 5.9 , compared to mean changes of $-0.06 \%$ and 3.4. So both models had larger variability in COD than CC changes.

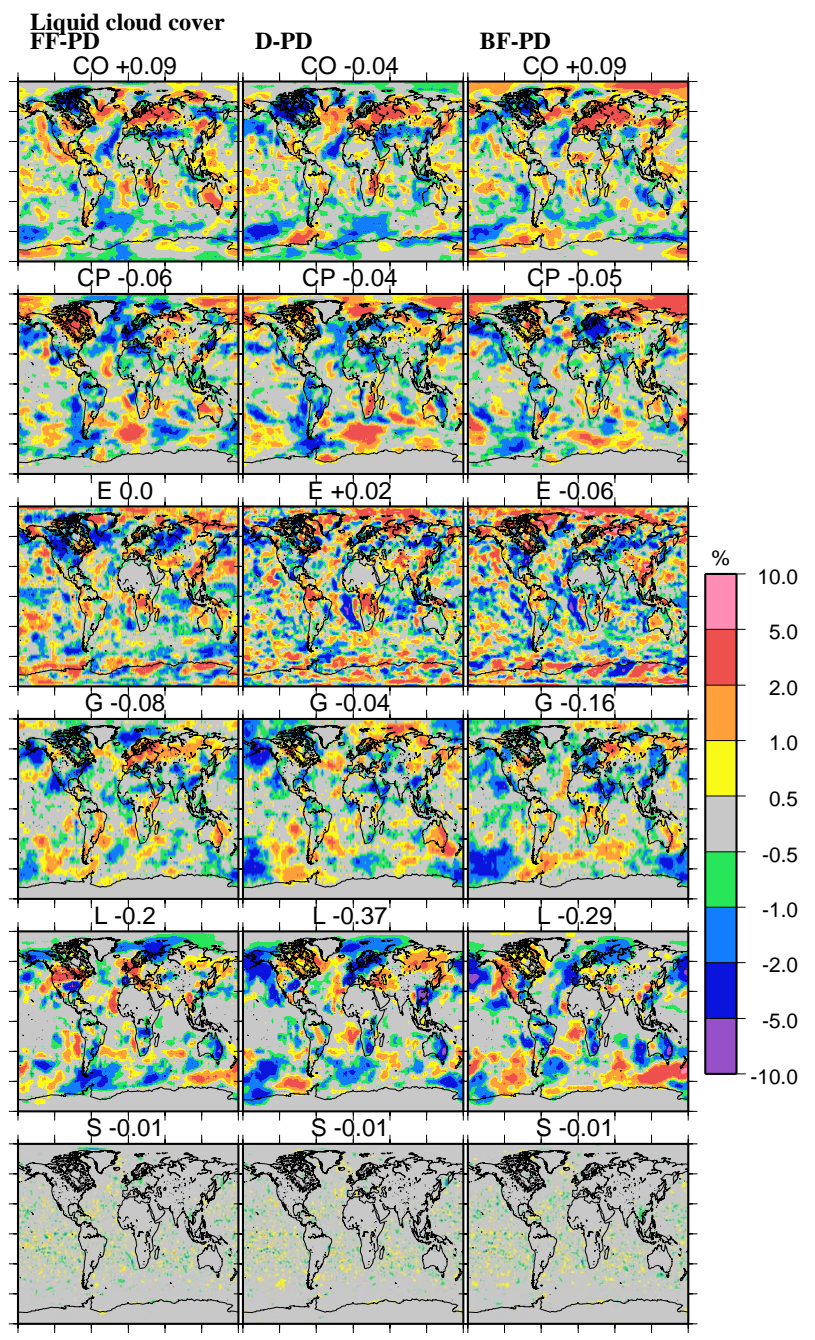

Fig. 5. Difference in annual cloud cover from the fossil fuel (left), diesel (middle) and biofuel (right) reduction experiments and the full simulation. All results are for liquid cloud cover except $E$ which is low cloud cover. Each row is one model.

All-sky (net) TOA flux changes for the experiments are also provided in Table 4. The average all-sky flux change for $\mathrm{FF}$ is $-0.1 \mathrm{Wm}^{-2}$ and for $\mathrm{BF}$ is $+0.06 \mathrm{Wm}^{-2}$. The respective average cloudy-sky flux changes are $-0.08 \mathrm{Wm}^{-2}$ and $+0.11 \mathrm{Wm}^{-2}$, and the all-sky and the cloudy-sky values generally have the same sign for most experiments. There is large variation among the models and the experiments in the relative importance of clear and cloudy sky flux changes. Note that it is not straightforward from our experiments to provide direct effects distinct from indirect effects, again because the cloudy-sky fluxes include abovecloud soot absorption. 


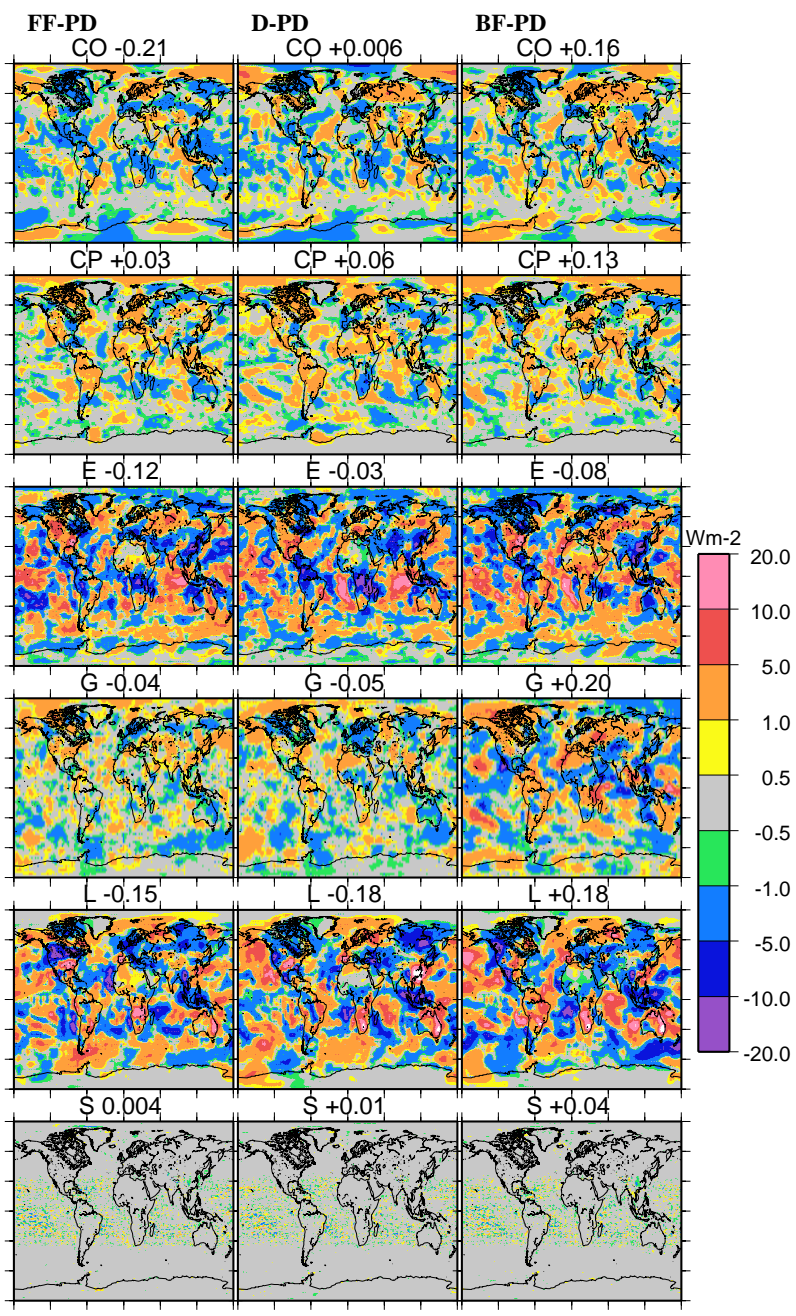

Fig. 6. Annual mean radiative flux change at top-of-atmosphere for cloudy-sky between the fossil fuel (left), diesel (middle) and biofuel (right) reduction experiments and the full simulation. L and E models use short-wave flux only. Each row is one model.

\section{Discussion and conclusions}

We have provided a multi-model investigation of how soot may affect liquid-clouds, by comparing results from three soot-reduction experiments in six global models. We have presented the results for top-of-atmosphere cloudy-sky radiative flux and other cloud changes, due to a combination of indirect and semi-direct effects. The experiments indicate a large diversity in response, but with some robust tendencies.

Reductions of all biofuel $\mathrm{BC}$ and $\mathrm{OC}$ (BF), which accounts for approximately $20 \%$ and $10 \%$ of all respective $\mathrm{BC}$ and $\mathrm{OC}$ sources, results in a positive cloudy-sky radiative response in all models except one, ranging from 0.08 to $+0.20 \mathrm{Wm}^{-2}$. Removal of biofuel soot decreased the $\mathrm{CCN}$ and $\mathrm{CDNC}$ population because the biofuel $\mathrm{BC}$ -
OC particles were generally sufficiently large and hygroscopic. The average cloud response to biofuel soot (addition) is $-0.11 \mathrm{Wm}^{-2}$. This can be compared to the direct radiative effect of about $+0.08 \mathrm{Wm}^{-2}$ (Schulz et al., 2006; using the AeroCom model estimates and enhancing the $\mathrm{BC}$ component by $50 \%$ to account for internal mixing enhancement of absorption as recommended by Bond and Bergstrom, 2006). Therefore it appears that removal of biofuel soot could cause a warming due to the concurrent cloud effects.

A more idealized experiment, reducing all fossil fuel BC (FF), resulted in negative or small positive cloudy-sky radiative responses, from -0.28 to $+0.03 \mathrm{Wm}^{-2}$. The negative responses, obtained for four of the models, occured mostly because the removal of soot enabled growth of bigger, more hygroscopic particles, resulting in increased CDNC and cloud optical depths. The average cloudy-sky radiative flux change to fossil fuel $\mathrm{BC}$ addition is $+0.08 \mathrm{Wm}^{-2}$ and therefore a contributor to global warming. However, to treat the fossil fuel experiments realistically we should change $\mathrm{OC}$ and $\mathrm{SO}_{2}$ co-emissions as well. For example coal combustion has large $\mathrm{SO}_{2}$ emission, and it is possible that reduction of coemmitted $\mathrm{SO}_{2}$ would largely eliminate the cloud enhancement the models found in their FF experiments.

For most models, the diesel-reduction experiments tended to have small cloudy-sky radiative response (less than $\pm 0.06 \mathrm{Wm}^{-2}$ in all but one model), in part because the emission magnitude is smaller. The reduced emissions for $\mathrm{D}$ are also intermediate in properties between those for $\mathrm{BF}$ and $\mathrm{F}$, with a small amount of $\mathrm{OC}$ enhancing hygroscopicity but with the smaller particle size as assumed for fossil fuel combustion. For most models the cloudy radiative flux changes for D are similar to the FF experiment, however two models had much smaller response, so the average radiative flux change was $-0.03 \mathrm{Wm}^{-2}$. However the signal to noise ratio may be small in these experiments.

Overall, the results of these experiments are consistent with the previous studies. As in Chen et al. (2010), Bauer et al. (2010) and Jacobson (2010), biofuels are found to enhance cloud, and consistent with the first two of these, biofuel soot has a negative cloud radiative response. Consistent with all three studies, all models have less negative response to fossil fuel compared to biofuel soot.

Our experiments highlight several uncertainties in the cloud-soot responses. Most obvious is the diversity in response among and within models. The experiment cloud responses had large interannual variability and standard deviation. Two of the models had standard deviation larger than the radiative response and one had standard deviation smaller by a factor of four. These are similar to what was found by Chen et al. (2010) in which their biofuel and fossil fuel experiments had respective standard deviation smaller by one-third and about equal to the radiative flux changes. Our simulations were performed for five years, and longer experiments should be conducted when considering the effects on clouds from relatively small aerosol perturbations. 
Detection of similarities may also be hindered by variation in wavelength of cloud responses, possibly resulting from different model resolutions. Some models also had larger changes over land or ocean while others had similar changes over both. There was very little robustness in how models responded in particular regions to soot reductions. Rather, the responses may largely reflect cloud changes characteristic for the model, as seen in the similarity in CC changes for the three soot-reduction experiments conducted by each experiment (Fig. 5).

While both COD and CC changes apparently influence the cloudy-sky radiative flux changes, Quaas et al. (2009) found that the models generally overestimated the LWP-AOD relation but underestimated the CC-AOD relation, compared with satellite retrievals. Since most of the soot-reduction experiments (14 out of 18) had reduced cloud cover, stronger cloud cover response would tend to cause more positive radiative flux change.

The CC responses for these experiments also included a combination of cloud-lifetime change from aerosol microphysics and the response of the clouds to aerosol absorption perturbation of the atmospheric thermal structure (semidirect effect). The semi-direct effect responses probably involve a combination of cloud increase and decrease for various regions, however some global models have a net negative cloud response to absorbing aerosols, which increases with aerosol absorption (Koch and Del Genio, 2010). This semi-direct effect may therefore contribute to the negative cloud forcing response, or to a cloud cover loss (positive response) from the soot-reduction experiments, although we cannot at this point document the impact of the semi-direct effect on these experiments. Future experiments might isolate the indirect from the semi-direct effect, as was done in Chen et al. (2010) by switching off the aerosol-radiation interaction. However these cloud effects probably interact and therefore do not add linearly. Furthermore, ultimately we are interested in the net effect of soot and co-emitted species on climate, including semi-direct, direct, indirect and snow/icealbedo effects together.

The radiative effects also include the direct effect occurring above-cloud in the cloudy-sky region. This effect would cause the cloudy-sky flux to be more negative in the soot removal experiments. The effect would tend to be proportional to the change in $\mathrm{BC}$ emission, which was largest for the $\mathrm{FF}$ experiment (BC emission change is 3, 1.6 and 1.3 for $\mathrm{FF}, \mathrm{BF}$ and D).

Our experiments suggest the importance of several influences on $\mathrm{CCN}$ activity. These conclusions are qualitative because we did not have $\mathrm{CCN}$ diagnostics from all models to help quantify the changes. CDNC was reduced most effectively by biofuel removal, due to the larger sizes and hygroscopicity of the $\mathrm{BC}-\mathrm{OC}$ particles. In addition, the emission reduction was greatest for the $\mathrm{BF}$ experiment. CDNC was reduced less or even increased when fossil fuel $\mathrm{BC}$ was removed. These particles are smaller, less hygroscopic and therefore less active $\mathrm{CCN}$. When these particles were removed, secondary species (e.g. sulfate) nucleated more and/or condensed on other particles such as OC, and this particle population was sometimes more easily activated than the population including fossil fuel BC. Such non-linear interactions between soot and sulfate have also been observed in the field (Lee et al., 2006). In order for models to capture these effects, their aerosol microphysical schemes need to accurately simulate particle size, hygroscopicity, mixing and nucleation. Global models are only beginning to compare their aerosol mixtures with relevant field measurements; more testing of the microphysical schemes is needed before we can be confident in how they simulate cloud responses to soot reduction.

One difficulty highlighted by these simulations are the significant non-linearities, not only those resulting from the indirect effect itself, but also those due to competing effects that influence the CCN population. It is already known that the indirect effect is most potent in clean conditions, so that removing particles from a highly polluted environment would have a relatively smaller impact. Here we have argued that soot removal can either increase or decrease $\mathrm{CCN}$ and the size and sign of the cloud response depend on the composition of the soot (OC to $\mathrm{BC}$ ratio, with OC usually assumed to be more hygroscopic), the size of the particles, as well as the magnitude of the soot change. Future experiments should focus on controlling these variables individually in order to quantify the non-linearities. A challenge will be to define the non-linearities by making incremental changes in emissions, and yet obtain statistically significant cloud responses. And yet, with the need to understand whether reductions of soot sources benefits climate, it is these smaller emission changes that are most relevant for policy purposes.

Acknowledgements. We acknowledge two anonymous reviewers for their helpful comments on our manuscript. We thank Tami Bond for providing diesel emissions for the experiments and for comments on the manuscript. D. Koch was supported by the NASA MAP Program and the Clean Air Task Force. The work with CAM-Oslo was supported by the projects EUCAARI (European Integrated project No. 036833-2), IPY POLARCAT and NorClim (Norwegian Research Council grants No. 178246 and 460724) and by the Norwegian Research Council's program for Supercomputing through a grant of computer time. R. C. Easter, S. J. Ghan, and X. Liu were funded by the US Department of Energy, Office of Science, Scientific Discovery through Advanced Computing (SciDAC) program. The Pacific Northwest National Laboratory is operated for DOE by Battelle Memorial Institute under contract DE-AC06-76RLO 1830. The work at LBNL was supported by US DOE under Contract No. DE-AC02-05CH1123. S. Menon acknowledges support from the NASA MAP and the DOE ASR and Global Climate Modeling Program.

Edited by: J. H. Seinfeld 


\section{References}

Abdul-Razzak, H. and Ghan, S. J.: A parameterization of aerosol activation, 2. Multiple aerosol types, J. Geophys. Res., 105(D5), 6837-6844, 2000.

Balkanski, Y., Myhre, G., Gauss, M., Rädel, G., Highwood, E. J., and Shine, K. P.: Direct radiative effect of aerosols emitted by transport: from road, shipping and aviation, Atmos. Chem. Phys., 10, 4477-4489, doi:10.5194/acp-10-4477-2010, 2010.

Bauer, S. E., Wright, D. L., Koch, D., Lewis, E. R., McGraw, R., Chang, L.-S., Schwartz, S. E., and Ruedy, R.: MATRIX (Multiconfiguration Aerosol TRacker of mIXing state): an aerosol microphysical module for global atmospheric models, Atmos. Chem. Phys., 8, 6003-6035, doi:10.5194/acp-8-60032008, 2008.

Bauer, S. E., Menon, S., Koch, D., Bond, T. C., and Tsigaridis, K.: A global modeling study on carbonaceous aerosol microphysical characteristics and radiative effects, Atmos. Chem. Phys., 10, 7439-7456, doi:10.5194/acp-10-7439-2010, 2010.

Berry, E. X.: Cloud droplet growth by collection, J. Atmos. Sci., 24, 688-701, 1967.

Bond, T. C. and Bergstrom, R. W.: Light absorption by carbonaceous particles: An investigative review, Aerosol Sci. Technol., 40, 27-67, 2006.

Bond, T. C., Streets, D. G., Yarber, K. F., Nelson, S. M., Woo, J.H., and Klimont, Z.: A technology-based global inventory of black and organic carbon emissions from combustion, J. Geophys. Res., 109, D14203, doi:10.1029/2003JD003697, 2004.

Bony, S. and Emanuel, K. E.: A parameterization of the cloudiness associated with cumulus convection; evaluation using TOGA COARE data, J. Atmos. Sci., 58, 3158-3183, 2001.

Chen, W.-T., Lee, Y. H., Adams, P. J., Nenes, A., and Seinfeld, J. H.: Will black carbon mitigation dampen aerosol indirect forcing?, Geophys. Res. Lett., 37, L09801, doi:10.1029/2010GL042886, 2010.

Chuang, C. C., Penner, J. E., Prospero, J. M., Grant, K. E., Rau, G. H., and Kawamoto, K.: Cloud susceptibility and the first aerosol indirect forcing: Sensitivity to black carbon and aerosol concentrations, J. Geophys. Res., 107(D21), 4564, doi:10.1029/2000JD000215, 2002.

Dentener, F., Kinne, S., Bond, T., Boucher, O., Cofala, J., Generoso, S., Ginoux, P., Gong, S., Hoelzemann, J. J., Ito, A., Marelli, L., Penner, J. E., Putaud, J.-P., Textor, C., Schulz, M., van der Werf, G. R., and Wilson, J.: Emissions of primary aerosol and precursor gases in the years 2000 and 1750 prescribed data-sets for AeroCom, Atmos. Chem. Phys., 6, 4321-4344, doi:10.5194/acp6-4321-2006, 2006.

Easter, R. C., Ghan, S. J., Zhang, Y., Saylor, R. D., Chapman, E. G., Laulainen, N. S., Abdul-Razzak, H., Leung, L. R., Bian, X., and Zaveri, R. A.: MIRAGE: Model description and evaluation of aerosols and trace gases, J. Geophys. Res., 109, D20210, doi:10.1029/2004JD004571, 2004.

Hansen, J., Sato, M., and Ruedy, R.: Radiative forcing and climate response, J. Geophys. Res.-Atmos., 102, 6831-6864, 1997.

Hoose, C., Kristjansson, J. E., Iversen, T., Kirkevag, A., Seland, O., and Gettelman, A.: Constraining cloud droplet number concentration in GCMs suppresses the aerosol indirect effect, Geophys. Res. Lett., 36, L12807, doi:10.1029/2009GL038568, 2009.

Jacobson, M. Z.: Control of fossil-fuel particulate black carbon and organic matter, possibly the most effective method of slowing global warming, J. Geophys. Res., 107(D19), 4410, doi:10.1029/2001JD001376, 2002.

Jacobson, M. Z.: Effects of absorption by soot inclusions within clouds and precipitation on global climate, J. Phys. Chem., 110, 6860-6873, 2006.

Jacobson, M. Z.: Short-term effects of controlling fossil-fuel soot, biofuel soot and gases, and methane on climate, Arctic ice, and air pollution health, J. Geophys. Res., 115, D14209, doi:10.1029/2009JD013795, 2010.

Kanakidou, M., Seinfeld, J. H., Pandis, S. N., Barnes, I., Dentener, F. J., Facchini, M. C., Van Dingenen, R., Ervens, B., Nenes, A., Nielsen, C. J., Swietlicki, E., Putaud, J. P., Balkanski, Y., Fuzzi, S., Horth, J., Moortgat, G. K., Winterhalter, R., Myhre, C. E. L., Tsigaridis, K., Vignati, E., Stephanou, E. G., and Wilson, J.: Organic aerosol and global climate modelling: a review, Atmos. Chem. Phys., 5, 1053-1123, doi:10.5194/acp-5-1053-2005, 2005.

Kärcher, B., Möhler, O., DeMott, P. J., Pechtl, S., and Yu, F.: Insights into the role of soot aerosols in cirrus cloud formation, Atmos. Chem. Phys., 7, 4203-4227, doi:10.5194/acp-7-4203-2007, 2007.

Khairoutdinov, M. and Kogan, Y.: A new cloud physics parameterization in a large-eddy simulation model of marine stratocumulus, Mon. Weather Rev., 128, 229-243, 2000.

Koch, D. and Del Genio, A. D.: Black carbon semi-direct effects on cloud cover: review and synthesis, Atmos. Chem. Phys., 10, 7685-7696, doi:10.5194/acp-10-7685-2010, 2010.

Kristjansson, J.: Studies of the aerosol indirect effect from sulfate and black carbon aerosols, J. Geophys. Res., 107(D15), 4246, doi:10.1029/2001JD000887, 2002.

Lee, Y. S., Collins, D. R., Li, R., Bowman, K. P., and Feingold, G.: Expected impact of an aged biomass burning aerosol on cloud condensation nuclei and cloud droplet concentrations, J. Geophys. Res., 111, D22204, doi:10.1029/2005JD006464, 2006.

Lin, H. and Leaitch, R.: Development of an in-cloud aerosol activation parameterization for climate modelling. In: Proc. WMO Workshop on Measurements of Cloud Properties for Forecasts of Weather, Air Quality and Climate, Mexico City, 1997.

Liu, X., Penner, J. E., and Wang, M.: Influence of anthropogenic sulfate and soot on upper tropospheric clouds using CAM3 coupled with an aerosol model, J. Geophys. Res., 114, D03204, doi:10.1029/2008JD010492, 2009.

Lohmann, U., Stier, P., Hoose, C., Ferrachat, S., Kloster, S., Roeckner, E., and Zhang, J.: Cloud microphysics and aerosol indirect effects in the global climate model ECHAM5-HAM, Atmos. Chem. Phys., 7, 3425-3446, doi:10.5194/acp-7-3425-2007, 2007.

Lohmann, U. and Hoose, C.: Sensitivity studies of different aerosol indirect effects in mixed-phase clouds, Atmos. Chem. Phys., 9, 8917-8934, doi:10.5194/acp-9-8917-2009, 2009.

Morrison, H. and Gettelman, A.: A new two-moment bulk stratiform cloud microphysics scheme in the Community Atmosphere Model, version 3 (CAM3), Part I: Description and numerial tests, J. Climate, 21, 3642-3659, 2008.

Penner, J. E., Chen, Y., Wang, M., and Liu, X.: Possible influence of anthropogenic aerosols on cirrus clouds and anthropogenic forcing, Atmos. Chem. Phys., 9, 879-896, doi:10.5194/acp-9-8792009, 2009.

Quaas, J., Ming, Y., Menon, S., Takemura, T., Wang, M., Penner, 
J. E., Gettelman, A., Lohmann, U., Bellouin, N., Boucher, O., Sayer, A. M., Thomas, G. E., McComiskey, A., Feingold, G., Hoose, C., Kristjánsson, J. E., Liu, X., Balkanski, Y., Donner, L. J., Ginoux, P. A., Stier, P., Grandey, B., Feichter, J., Sednev, I., Bauer, S. E., Koch, D., Grainger, R. G., Kirkevåg, A., Iversen, T., Seland, Ø., Easter, R., Ghan, S. J., Rasch, P. J., Morrison, H., Lamarque, J.-F., Iacono, M. J., Kinne, S., and Schulz, M.: Aerosol indirect effects general circulation model intercomparison and evaluation with satellite data, Atmos. Chem. Phys., 9, 8697-8717, doi:10.5194/acp-9-8697-2009, 2009.

Rasch, P. J. and Kristjánsson, J. E.: A comparison of the CCM3 model climate using diagnosed and predicted condensate parameterizations, J. Climate, 11, 1587-1614, 1998.

Rotstayn, L. D. and Liu, Y.: A smaller global estimate of the second indirect aerosol effect, Geophys. Res. Lett., 32, L05708, doi:10.1029/2004GL021922, 2005.

Schulz, M., Textor, C., Kinne, S., Balkanski, Y., Bauer, S., Berntsen, T., Berglen, T., Boucher, O., Dentener, F., Guibert, S., Isaksen, I. S. A., Iversen, T., Koch, D., Kirkevåg, A., Liu, X., Montanaro, V., Myhre, G., Penner, J. E., Pitari, G., Reddy, S., Seland, Ø., Stier, P., and Takemura, T.: Radiative forcing by aerosols as derived from the AeroCom present-day and pre-industrial simulations, Atmos. Chem. Phys., 6, 5225-5246, doi:10.5194/acp-6-5225-2006, 2006.
Seland, $\varnothing$, Iversen, T., Kirkevåg, A., and Storelvmo, T.: On basic shortcomings of aerosol-climate interactions in atmospheric GCMs, Tellus, 60A, 459-491, doi:10.1111/j.16000870.2008.00318.x, 2008.

Stier, P., Feichter, J., Kinne, S., Kloster, S., Vignati, E., Wilson, J., Ganzeveld, L., Tegen, I., Werner, M., Balkanski, Y., Schulz, M., Boucher, O., Minikin, A., and Petzold, A.: The aerosolclimate model ECHAM5-HAM, Atmos. Chem. Phys., 5, 11251156, doi:10.5194/acp-5-1125-2005, 2005.

Storelvmo, T., Kristj'ansson, J. E., Ghan, S. J., Kirkevåg, A., Seland, Ø., and Iversen: Predicting cloud droplet number concentration in Community Atmosphere Model (CAM)-Oslo, J. Geophys. Res., 111, D24208, doi:10.1029/2005JD006300, 2006.

Takemura, T., Nozawa, T. T., Emori, S., Nakajima, T. Y., and Nakajima, T.: Simulation of climate response to aerosol direct and indirect effects with aerosol transport-radiation model, J. Geophys. Res., 110, D02202, doi:10.1029/2004JD005029, 2005. 